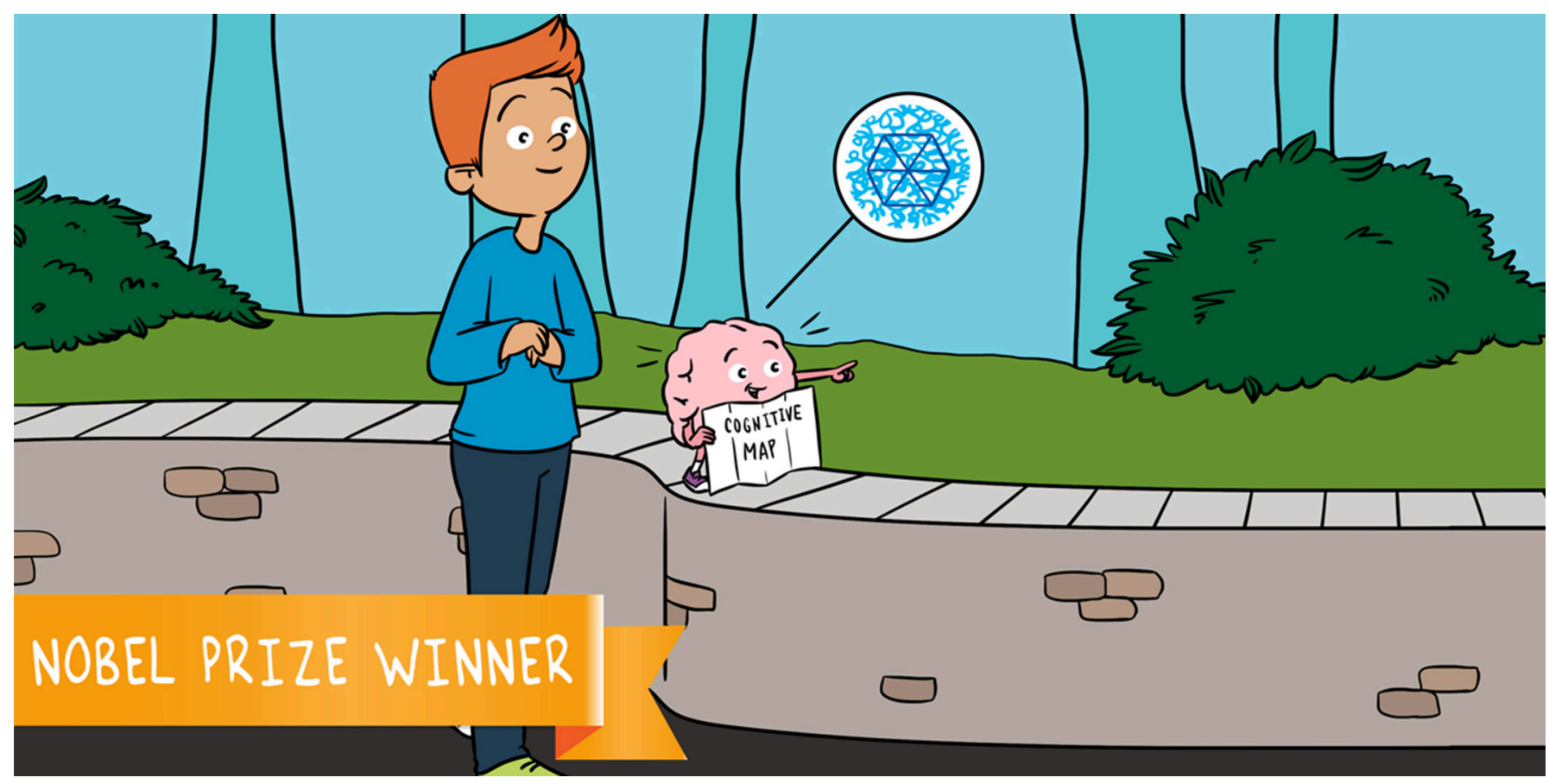

\title{
HOW DO WE FIND OUR WAY? GRID CELLS IN THE BRAIN
}

\section{May-Britt Moser *}

Centre for the Biology of Memory, Medical-Technical Research Centre, Norwegian University of Science and Technology, Trondheim, Norway

\section{YOUNG REVIEWERS:}

ORT DAFNA

HIGH SCHOOL ISRAEL

AGES: 14-15
Navigation in the environment, getting from one place to another, is one of the most fundamental and vital skills in the animal kingdom, and for humans, too. To navigate successfully, an animal needs to create an internal "cognitive map" of the outside environment. This is performed by a specific system in the brain, containing several brain regions and various cell types, each with its unique role in navigation. In this article, I will outline some of the main components of this internal navigation system, focusing on the grid cells, an amazing and surprising group of nerve cells that we discovered, which create a coordinate system in the brain. I will end with a few general recommendations for you, based on my own life experiences.

Prof. May-Britt Moser won the Nobel Prize in Physiology or Medicine in 2014 for the discovery of cells that constitute a positioning system in the brain.

Interviewed and co-written by Noa Segev, graduate of the Grand Technion Energy Program, Technion, Israel Institute of Technology, Haifa, Israel. 
Figure 1

Place cells in the hippocampus participate in building an inner map of the environment. Place cells are found in the hippocampus of both mouse and human brains (light brown). White lines in the box show the running path of a rat in a laboratory environment. The red region shows the location where a specific place cell in the hippocampus (black dot on the rat's hippocampus) becomes strongly active. This is the location that this specific place cell represents. Different place cells are active when the rat is at different locations; together they build an inner, cognitive map of the environment (Adapted from here).

\section{GRID CELLS}

Nerve cells in a brain area called the entorhinal cortex, which create a "coordinate map" in the brain that enables navigation and metric (how far and in which direction) in the environment.

1 If you want to learn more about the GPS navigation system, click here.

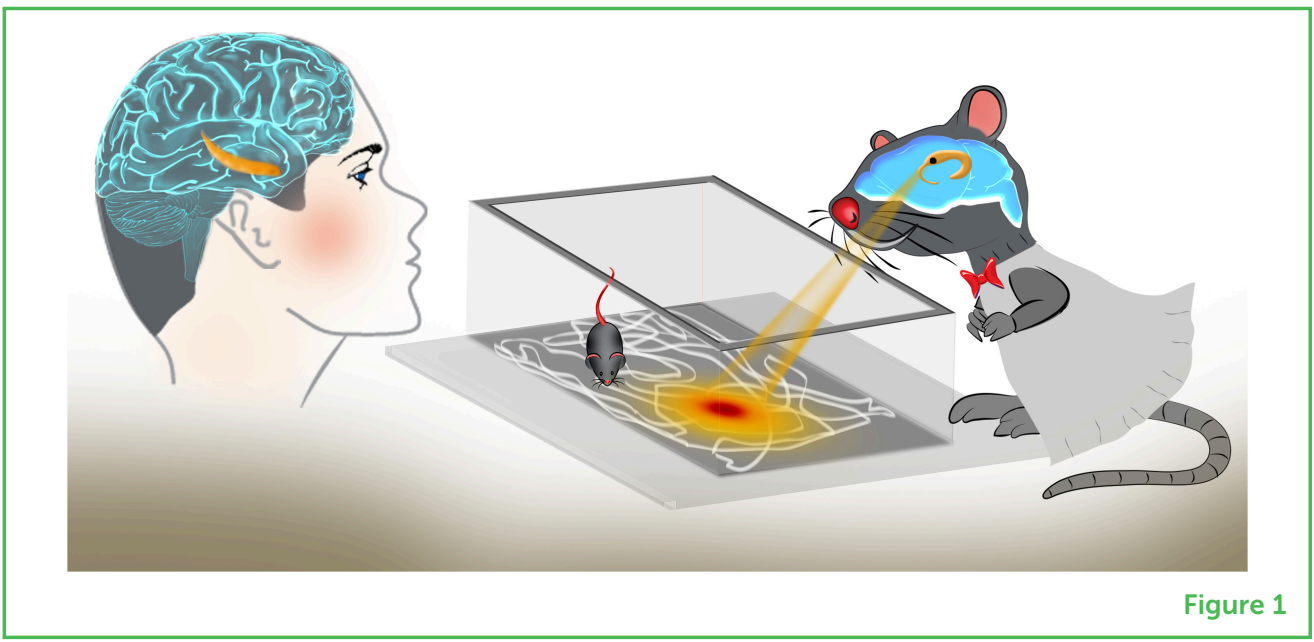

When you think about navigation, what is the first thing that comes to mind? Is it the well-known GPS system in your cellphone? An underwater journey of a submarine to its destination? Or perhaps a team assignment in the scouts, to find your way back to the camp at night? What if I told you that your brain has a built-in navigation system that is responsible for representing your location in the environment and for orienting you so that you can successfully get from one place to another? This mental representation of the environment is often called a cognitive map. While navigation in the environment appears seamless and automatic, the brain's navigation system is actually quite complex, composed of several brain regions and various cells types. This article will lead you through a journey of riddles about navigation, which will eventually bring you to a very special system of nerve cells in the brain called grid cells, a positioning system that we have discovered and for which we received a Nobel Prize in 2014.

\section{STEP 1: WHERE ARE YOU NOW?}

To start navigating in the environment, what is the first step that is required? You guessed it! You need to know where you are currently located. Can you think of a way that the brain figures out where you are located right now? I will give you a hint-it is different from the way the GPS in your cellphone determines your location. As you may know, GPS uses signals sent from at least four different satellites orbiting around the earth. Using mathematical calculations based on advanced physics, these satellite signals are used by your cellphone to determine your location with great accuracy ${ }^{1}$. But does the brain receive signals from an outside source to determine your location? The answer is no. So, what does your brain do to determine where you are? Try to think of at least two possible solutions to this riddle before moving on to the next paragraph. 
PLACE CELLS

Nerve cells in a brain area called hippocampus, which tell the animal where it is located in space. Each place cell becomes active in one specific location in the environment. It differentiates between environments by not being active or being active in a very different place in the new environment from what would be expected in the other environment [1]

\section{SPEED CELLS}

Nerve cells whose activity "reports" on the speed in which the animal moves by increasing their activity when the animal moves faster. These cells are located in the entorhinal cortex and are used by the animal to calculate the distance it passes in the course of its movement.

\section{ENTORHINAL} CORTEX

An area located deep in the brain, near the hippocampus, slightly beneath the ear level. This area is an important part of the navigation system (the "cognitive map") of the brain, and it contains, among others, the grid cells, head direction cells and speed cells.
It turns out that, in the brain, there are nerve cells that represent your location, called place cells. In 1971, two researchers named John O'Keefe and John Dostrovsky were studying the electrical activity in rat brains [2]. When they looked at a brain region called the hippocampus, they saw that when the animal was at a specific place in its environment, certain nerve cells became active and started firing electrical signals at a high rate (Figure 1). Other place cells were activated when the rat was in different locations. In other words, if you are standing in a particular location in your room, there is a specific place cell in your hippocampus that is strongly active, and this cell tells you where you are. The electrical activity of these place cells is so precise that, if we simultaneously record the activity of 100 of them for a while, we can accurately predict the location of a rat within 5 $\mathrm{cm}$ ! This is quite extraordinary, as these cells are deep in the brain, far from the senses; they do not have eyes or ears, or any other sense organ, so how do these place cells get their information about the environment?

\section{STEP 2: HOW FAR DID YOU GO AND WHERE DID YOU ARRIVE AT?}

Let us say that you figured out that you are standing in a specific place, using a specific place cell. You then walked for a while and determined your new location, using another place cell. But how do you know the distance between these two locations? In other words, how do you know the relative location of the two places? First, try to think of what you need to know to calculate the distance between two points. If I told you that I was walking for 2 min, what would you ask me to determine how far I walked? That is right, you would need to know my walking speed. The brain solves this problem with the help of speed cells [3], which tell you the speed at which you are moving. These cells are not located in the hippocampus, but rather in a different, deep brain region called the entorhinal cortex.

If you knew my starting location, my walking speed, and how long I walked for, could you tell where am I now? Or is additional information needed? For example, if you knew that the starting point and the destination point are $100 \mathrm{~m}$ apart, could you tell where I am on the circle around my starting point, which has a radius of $100 \mathrm{~m}$ ? (Figure 2). The answer is no. The additional information you need is direction. The brain also has head direction cells, which are found in several brain areas [4]. When these cells are active, they inform the animal of what direction it is moving. Knowing your initial location, your walking speed and time, and the direction of your walk, you can know exactly where you are now relative to where you started (Figure 2). 
Figure 2

To navigate

successfully in the environment, you need to know your starting position (A), target location (B), walking direction, and speed. Knowing that you started walking from a given location (using place cells) and walked for 2 min at a speed of $50 \mathrm{~m}$ per minute (using speed cells), you know that you traveled a total of $100 \mathrm{~m}$. But can you determine where exactly you are on the circle with a radius of $100 \mathrm{~m}$ around you? No! (blue dashed lines). For this, you need head direction cells, which provide the direction you are heading (red dashed line).

2 Watch this video to see https://www. youtube.com/ watch? $v=i 9 \mathrm{Gi}$ LBXWAHI.

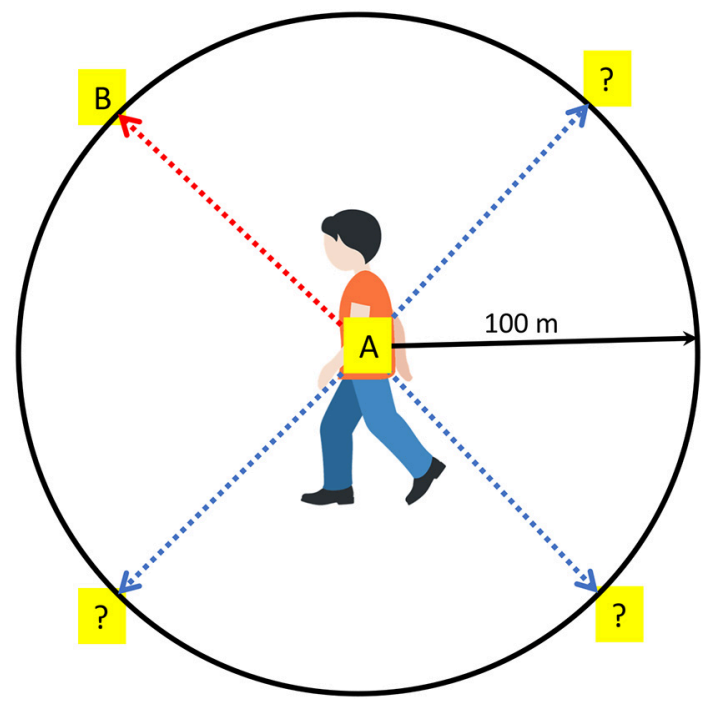

Figure 2

\section{STEP 3: ARE THERE OTHER WAYS TO FIND YOUR LOCATION AND GET FROM A TO B? GRID CELLS}

Here is a difficult (but rewarding) riddle. To navigate from location A to location $B$, we saw that it is enough to know the initial place, the speed, the time, and the direction of movement. However, to the surprise of many brain researchers, the brain uses an additional and amazing trick to solve the problem of navigation. I will give you a hint: it is related to a coordinate system on a map. This brain system is called the grid cell system.

The grid cell system is located in the middle of the brain, a bit below the ear level, in a deep brain area called the entorhinal cortex (Figure 3, purple area), which is located close to the hippocampus. Unlike hippocampal place cells that become active when the animal passes through one specific location, a grid cell becomes active at many locations in the environment (Figure 3). Most surprising was the finding that these locations form a symmetric and extremely accurate crystal-like pattern, characterized by equilateral triangles connecting the centers of nearby locations. These locations, called coordinates, form a hexagonal (six-sided polygon) grid and, therefore, we decided to name these cells grid cells ${ }^{2}$. It is important to emphasize that the coordinate patterns of grid cells are generated within the brain, they do not exist in the outside world.

Each grid cell forms a unique pattern of coordinates, which is shifted with respect to the coordinates formed by other nearby grid cells. In this way, the whole environment is "filled" with grid patterns (Figure 4A). Using only one grid cell you cannot know where the animal is, because each grid cell is active in multiple locations, forming a grid. But, because of the shift in location between different grid cells, and because of the varying scales of the grids (Figure $4 \mathrm{C}$ ), it is possible 
Figure 3

Grid cells in the entorhinal cortex are activated at multiple locations, forming a symmetrical coordinate system in the brain. Grid cells are located in a brain region called the entorhinal cortex (purple). White lines in the box show the running path of a rat in an environment. The same grid cell becomes electrically active at multiple locations along the rat's path (purple circles). The locations where the grid cell fires are arranged in a highly symmetrical hexagonal grid.

3 You can watch these overlapping grid cell patterns and how it provides the location of the animal in this video.

\section{HEAD DIRECTION} CELLS

Nerve cells found in several brain areas that inform the animal in which direction it is heading. Each head direction cell fires only when the animal's head is facing in a specific direction in space (e.g., north-west, but it is a private/subjective map and does not follow magnetic poles). Thus, a cell which is active when the head is pointing north in one environment might fire to south in the other environment. And cells follow each other: if one cell is shifted $180^{\circ}$ in one environment all other cells would do the same.

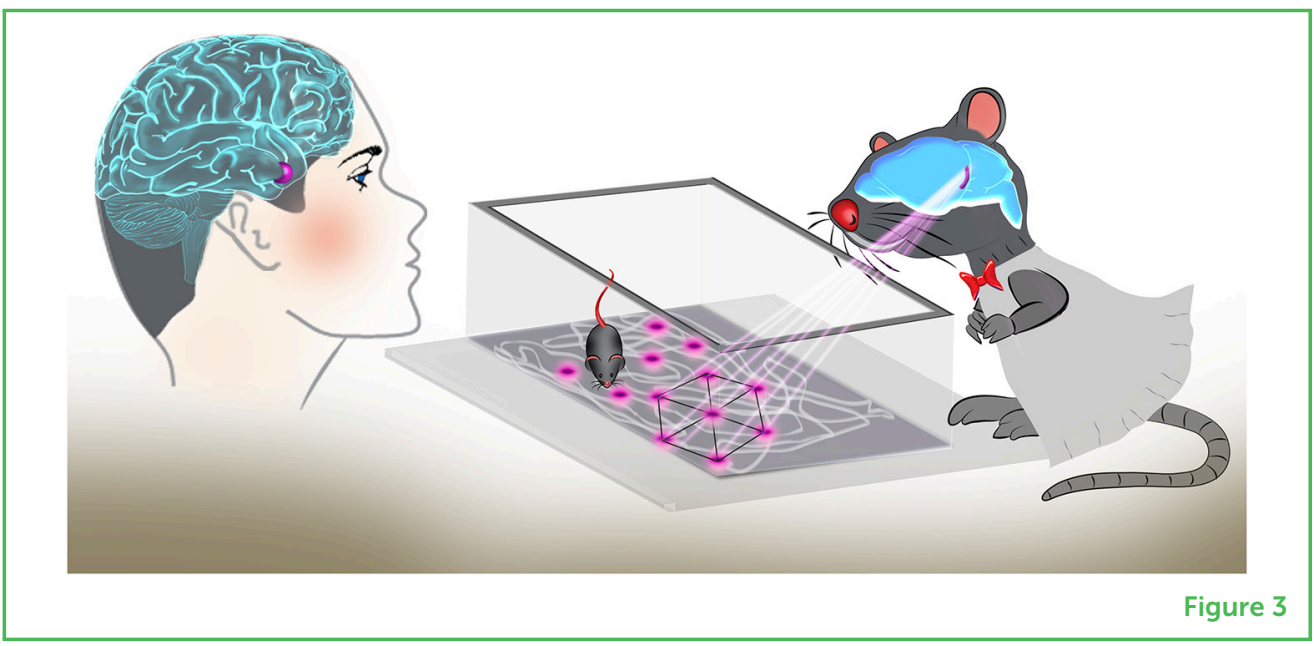

to define the animal's current location with great accuracy, using the overlapping grids of several cells ${ }^{3}$. These grid patterns serve as an internal map of coordinates in the brain and can also be used for measuring the distance between different points in space, a critical requirement for navigation (Figure 4B).

\section{MORE SURPRISES ABOUT GRID CELLS}

We found that the grid structure of the grid cells persists even when an animal walks in the dark [5]. We found that, to anchor the grid to the specific environment the animal is in (is it a large or a small room?), the animal uses sensory information, specifically visual information, such as cues on the walls and the location of the walls in the room. The grid patterns rotate when cues on the walls are rotated, and grids may expand or contract when one of the walls is moved to make the room larger or smaller. Interestingly, grid cells in different depths along the entorhinal cortex represent the same environment at different scales [5]. Grid cells located at the dorsal (upper) part of the entorhinal cortex fire at close physical locations of $\sim 25 \mathrm{~cm}$ apart (Figure $4 \mathrm{C}$, top right)-representing the environment with a fine ruler, whereas deeper (ventral) grid cells form a coarse ruler, as they fire at more distant locations of up to $3 \mathrm{~m}$ apart (Figure $4 \mathrm{C}$ ). Grid cells with varying scales all keep a similar symmetrical grid pattern.

Let me tell you yet another surprise about grid cells. Apparently, it is not only the brain that uses grid cells for successful and efficient navigation. In a fascinating study recently performed at an artificial intelligence company called DeepMind in London, U.K., researchers gave information about head direction and speed to a learning machine. The machine was supposed to learn to navigate in a new and challenging environment. After learning, the machine outperformed humans in navigating. Surprisingly, the machine spontaneously created artificial units with grid patterns, very similar to those of the grid cells in the brain [6]. What does this tell us? Even if the grid cell 
Figure 4

Grid cells coordinates map the environment. (A) Grid structure of three nearby grid cells (green, blue, and red), recorded

simultaneously when a rat was running in a circular environment The grid structure for the blue cell is highlighted by the light blue hexagon. The three cells have the same grid spacing and orientation but are shifted in space. (B) The grid structure could serve as a coordinate system for a cognitive map of the environment. (C) Grid cells located at the dorsal (upper) part of the entorhinal cortex (purple) represent the environment in fine scale (dense grid at top right), whereas ventral (deeper) grid cells form a coarse ruler (sparse grid at bottom right).

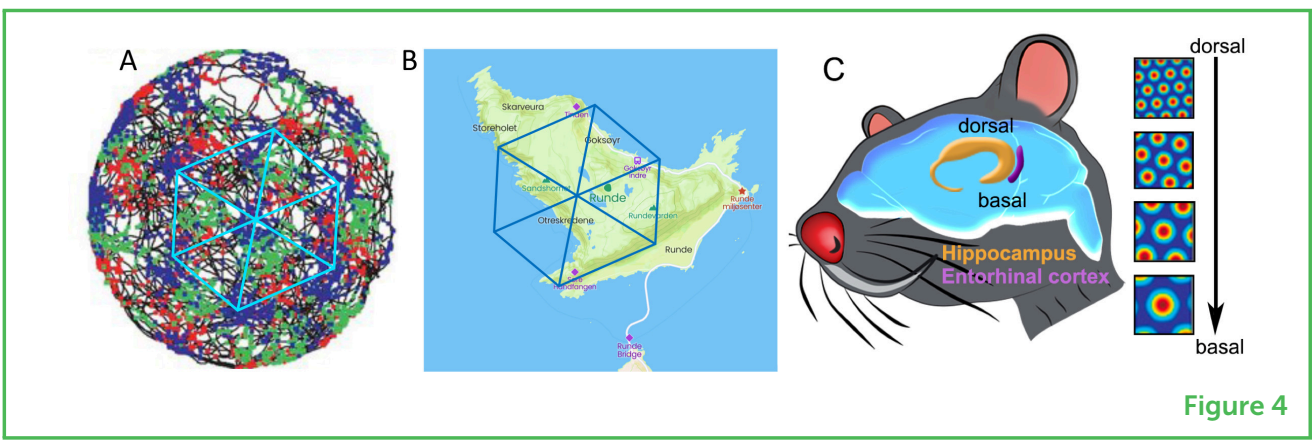

pattern is something that "just happened" during evolution, it must be extremely useful for navigation. We know that the brain is very efficient, and if there is a phenomenon (like grid cells) that is created almost by accident, it could become beneficial for the functioning of the animal. Think of it this way: imagine you receive a tool, such as a screwdriver, and you do not know what it is used for. As time passes, you will probably try to use the screwdriver in different circumstances, and eventually you will find ways that it is useful, right? The same holds true with the brain: it explores ways to use all the tools that it has, and finds ways that those tools are beneficial for the animal's survival.

Together, grid cells produce internal coordinate maps that allow an animal to navigate from one location to another. The grid cells work in unison with place cells and with other cell types, such as head direction cells and speed cells. This navigation system also integrates information from the senses, to calibrate the internal maps with the environment. This whole navigation system in the brain allows us to perform complex navigation tasks in a smooth and seamless manner. While we have learned a lot about this fascinating brain system, many aspects of it are yet unknown. For example: How does paying attention to cues in the environment or in memory affect the navigation system? How is the volume of an animal's body taken into account when the animal navigates? And what happens to the navigation system in a sick brain, such as in Alzheimer's disease, where cells in the entorhinal cortex die and the ability to navigate is lost? Another exciting question is how distance and direction between an animal and external objects are coded in the entorhinal cortex, and whether the cells also code for moving items like a ball in a soccer match [6]. These are challenging and important questions that could be part of a fascinating scientific journey for those of you who would like to become brain scientists.

\section{RECOMMENDATIONS FOR YOUNG MINDS}

As children and teenagers, you should remember that it is very difficult to understand what life will look like when you become an adult. I believe that it is important to maintain your curiosity about things, both now and as an adult, and to find something that you have a passion for, 
something that makes you feel enthusiastic and lively. I think that it is all about passion-your passion could be for math or physics, dance, writing, or anything else. You should always follow this internal drive and build your life around your strengths and your passion. Then your life will be much better than it would otherwise.

Many people will tell you which career you should have and why; because then you can get money or you earn a reputation, or you can get a Nobel Prize... but do not take this path. Go through the path that you feel is right for you. It might be anything that enriches you, that you like, that you can master. For myself, I can say that I am very curious about things and that it is extremely important for me to understand things. It gives me so much pleasure when I understand something that I did not understand before-this is my leading star.

Lastly, as a woman who won the Nobel Prize, it is important for me to emphasize that when you find your passion, it should not matter whether you are a man or a woman. I always thought of myself as a person, and when I became a scientist-as a scientist. I did not think so much about the fact that I am a woman. I think of myself as a scientist who was very lucky and who worked very hard and have fantastic collaborators. This, eventually, led me to win a Nobel Prize. But, even though being a man or a woman is irrelevant when it comes to passion, we should all be aware that there are specific environments where people do try to push females aside. In these environments we all-both males and females-should strongly support females or other minorities.

\section{ACKNOWLEDGMENTS}

We thank Prof. Yoram Burak for his comments.

\section{REFERENCES}

1. Alme, C. B., Miao, C., Jezek, K., Treves, A., Moser, E. I., and Moser, M. B. (2014). Orthogonality of place maps in the hippocampus: eleven maps for eleven room. Proc. Natl. Acad. Sci. U.S.A. 111:18428-35. doi: 10.1073/pnas.1421056111

2. O'Keefe, J., and Dostrovsky, J. 1971. The hippocampus as a spatial map: preliminary evidence from unit activity in the freely-moving rat. Brain Res. 34:171-5. doi: 10.1016/0006-8993(71)90358-1

3. Kropff, E., Carmichael, J. E., Moser, M. B., and Moser, E. 2015. Speed cells in the medial entorhinal cortex. Nature 523:419-24. doi: 10.1038/nature14622

4. Taube, J. S., Muller, R. U., and Ranck, J. B. 1990. Head-direction cells recorded from the postsubiculum in freely moving rats. I. Description and quantitative analysis. J. Neurosci. 10:420-35.

5. Hafting, T., Fyhn, M., Molden, S., Moser, M. B., and Moser, E. I. 2005.

Microstructure of a spatial map in the entorhinal cortex. Nature 436:801-6. doi: 10.1038/nature03721 
6. Banino, A., Barry, C., Uria, B., Blundell, C., Lillicrap, T., Mirowski, P., et al. 2018. Vector-based navigation using grid-like representations in artificial agents. Nature 557:429-33. doi: 10.1038/s41586-018-0102-6

7. Høydal, Ø. A., Skytøen, E. R., Andersson, S. O., Moser, M. B., and Moser, E. I. (2019). Object-vector coding in the medial entorhinal cortex. Nature 568:400-4. doi: 10.1038/s41586-019-1077-7

SUBMITTED: 10 March 2021; ACCEPTED: 07 April 2021; PUBLISHED ONLINE: 07 September 2021.

EDITOR: Idan Segev, Hebrew University of Jerusalem, Israel

CITATION: Moser M (2021) How Do We Find Our Way? Grid Cells in the Brain. Front. Young Minds 9:678725. doi: 10.3389/frym.2021.678725

CONFLICT OF INTEREST: The author declares that the research was conducted in the absence of any commercial or financial relationships that could be construed as a potential conflict of interest.

COPYRIGHT @ 2021 Moser. This is an open-access article distributed under the terms of the Creative Commons Attribution License (CC BY). The use, distribution or reproduction in other forums is permitted, provided the original author(s) and the copyright owner(s) are credited and that the original publication in this journal is cited, in accordance with accepted academic practice. No use, distribution or reproduction is permitted which does not comply with these terms.

\section{YOUNG REVIEWERS}

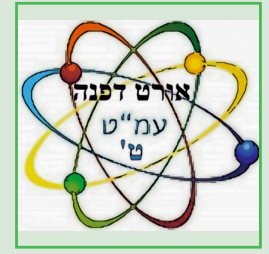

\section{ORT DAFNA HIGH SCHOOL ISRAEL, AGES: 14-15}

The students in this class study in a special program that focuses on physics, biology, mathematics, and computers sciences.

\section{AUTHOR}

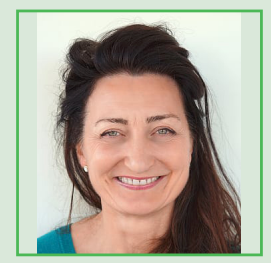

\section{MAY-BRITT MOSER}

I am a professor of neuroscience, the director of the Center for Neural Computation, and co-director at the Kavli Institute of Systems Neuroscience at the Norwegian University of Science and Technology in Trondheim. I received the Nobel Prize in Physiology or Medicine in 2014, together with my long-term colleagues Edvard Moser and John O'Keefe. I was born in a small town called Fosnavåg in Norway. I attended the University of Oslo, where I studied mathematics, physics, and chemistry. I was awarded a degree in psychology in 1990 and a Ph.D. in neurophysiology in 1995, supervised by Per Andersen. Edvard Moser's and my two daughters were born in 1991 and 1995. Both during my Ph.D. and until I returned to Norway in autumn of 1996, when both Edvard and I were appointed as associate professors in biological psychology at the Department of Psychology at the Norwegian University of Science and Technology (NTNU) in Trondheim, we worked in Richard Morris' lab at the Centre for Neuroscience, University of 
Edinburgh. In the summer of 1996, I was a visiting post-doctoral fellow at the laboratory of John O'Keefe at the University College, London, for 1 month. In 2000, I was promoted to a position of full professor of neuroscience, and at that time we moved to the medical faculty at NTNU. I am a member of the Royal Norwegian Society of Sciences and Letters, Norwegian Academy of Science and Letters, and the Norwegian Academy of Technological Sciences; an elected foreign associate of the National Academy of Sciences (USA), international member of the National Academy of Medicine (USA), and elected international member of the American Philosophical Society (USA). I have received numerous honors and prizes, including the Liliane Bettencourt pour les Sciences du Vivant in 2006, elected member of the European Molecular Biology Organization (EMBO) in 2012, 26th Louis-Jeantet Prize for Medicine (Louis-Jeantet Foundation) in 2011, the Andre Jahre Award in 2011, 13th Perl/UNC Neuroscience Prize (University of North Carolina) in 2013, Best Female Leader Award from Trondheim Business Society (Madame Beyer Award) in 2013, 47th Louisa Gross Horwitz Prize for Biology or Biochemistry (Columbia University) in 2013, 59th Karl Spencer Lashley Award (American Philosophical Society) in 2014, 30th Koerber European Science Prize (Koerber Foundation) in 2014, 102nd annual Fridtjof Nansen Award of Outstanding Research in Science and Medicine in 2013, Norwegian Academy of Science, Elected as a Fellow of the Association for Psychological Science for sustained and outstanding distinguished contributions to psychological science in 2018, and the Grand Cross of the Royal Norwegian Order of St. Olav (H.M. Harald of Norway) - the highest Royal Norwegian Order in 2018, and Gunerius gold medal 28th of February, awarded by the Royal Norwegian Academy for Sciences and Letters. *may-britt.moser@ntnu.no 